\title{
Total Phenolic Content and antioxidant activity of pure and formulated extracts of kesum (Polygonum Minus), bawang putih (Allivium Sativum), pegaga (Centella Asiatica), and ulam raja (Cosmos Caudatus)
}

Nooraini Zakaria, Sayang Baba, Ku Nurul Aqmar Ku Bahaudin, Salehhuddin Hamdana

Department of Biosciences and Health Sciences, Faculty of Biosciences and Medical Engineering, Universiti Teknologi Malaysia, 81310 UTM Johor Bahru, Johor, Malaysia.

*Corresponding Author: saleh65@utm.my

Article history :

Received 26 November 2015

Accepted 22 December 2015

\section{GRAPHICAL ABSTRACT}
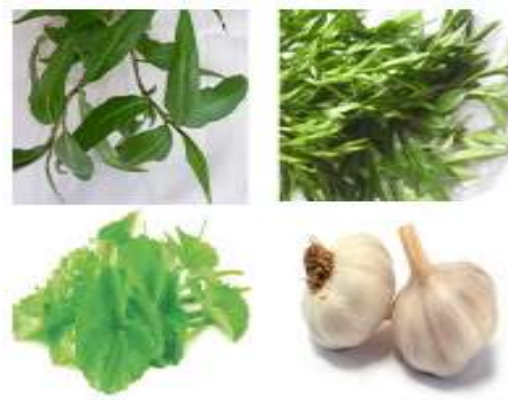

ABSTRACT

The use of herbs, spices, vegetables and medicinal plants have been traditionally utilize as the alternate medicinal to treat many of diseases by virtue of their antioxidant actions. Kesum, bawang putih, pegaga and ulam raja were extracted by using juice extractor without additional of solvent. The pure extracts were determined for moisture content and the pure and formulation extracts were analyzed for total phenolic content (TPC) and antioxidant activity (DPPH radical scavenging assay). The yield showed that kesum, bawang putih, pegaga and ulam raja extraction yield at $8.5 \%, 12 \%, 22.5 \%$ and $24 \%$ respectively. The results showed that, there was significant difference $(\mathrm{P}<0.05)$ in total phenolic content and antioxidant activity between pure and formulation extracts. Formulated kesum and bawang putih (1:0:0:1) extract had the highest total phenolic content $(1703.59 \pm 11 \mathrm{GAE} / 100 \mathrm{mg})$ followed by kesum pure extract $(1388.19 \pm 11 \mathrm{GAE} / 100 \mathrm{mg})$ and bawang putih pure extract $(1177.87 \pm 138.82$ GAE/100mg). No significant was noted and positive Pearson's correlations between TPC and DPPH assay ( $r=0.293$ ) was observed for all plants extract. The statistical indicated that phenolic compounds were not the main contributor of antioxidant activity in plants. Further, there was no synergistic effect observed for pure and formulation extracts.

Keywords: Kesum; bawang putih; ulam raja; pegaga; total phenolic content and DPPH radical scavenging assay

(C) 2015 Penerbit UTM Press. All rights reserved http://dx.doi.org/10.11113/mjfas.v11n4.399

\section{INTRODUCTION}

Phenolic compounds as a second metabolites, ubiquitous in herbs, spices and medicinal plants which have potential in promoting health and medical benefits [1]. Besides that, phenolic compounds contribute as an antioxidant by scavenging the superoxide anion, hydroxy radical, peroxy radical by inhibiting lipid peroxidation in the biological system [2]. Antioxidants activities in plants have been recognized by many researchers; for their potential in promoting health such as anti-viral [3]; anticancer [4]; anti-inflammatory [5]; anti-diabetic [6]; antiulcer [7] and etc. Synthetic antioxidants, such as butylated hygroxyanisole (BHA), butylated hydroxytoluene (BHT) and ter-butylhydroquinone (TBHQ) are commercially available currently in use. Unfortunately, it has been shown that they promote toxicity [8] and development of cancerous cells in rats [9]. In consequence, due to concern safety of synthetic antioxidants in food [10-12] and consumer demand for natural products [8]; have leads many researchers towards safer and more effective natural antioxidants from the edible plants as resources [12-14].
Numerous studies were conducted and had showed good antioxidant activities of kesum (Polygonum minus) [12, 15]; bawang putih (Allium sativum) [16]; pegaga (Centella asiatica) [17]; and ulam raja (Cosmos Caudatus) [18-19]. Kesum or scientific name Polygonum minus Huds is a medicinal herb and originated from Southeast Asia countries like Malaysia, Thailand, Vietnam and Indonesia. Among bioactive compounds reported was isolated from kesum that showed to have antioxidant activities, i.e: rutin, catechin, quercetin, isohamnetin, kaempherol [20], gallic acid, coumaric acid, rutin and quercetin [21]. Most of these compounds have been found valuable to use in pharmaceuticals, agrochemical, cosmetic, perfumery and food flavouring. For instance, farnesol has been has been suggested as anti-tumor agent and anti-bacterial activity [22]. Also, the gallic acid, coumaric acid, rutin and quercetin have possesses the anti-ulcer healing activities [21]. Bawang putih is a strongly aromatic bulb that has long been used in cooking and medicine. Lanzotti, 2012a [23], reported two major metabolites of bawang putih are sapogenin and saponin compounds such as furostane [24], 
spirostane [25] and cholestane [26]. These constituents had exhibited antispasmodic [27], antifungal [25], anti-ischemia

[28], cytotoxicity [29], haemolytic [30], and platelet antiaggregating activity [24].

Pegaga and ulam raja are commonly taken as traditional vegetable or 'ulam'. Pegaga has been reported to have sedative and anyxiolytic properties [17] and healing gastric ulcers [31]. Besides that, ulam raja is a rich source of bioactive compounds, including phenolics, flavonoids, carbohydrates, proteins, minerals and vitamins, increasing its nutritionary value [32]. Subjected by Ragasa et al. (1999) [33] have reported several anti-mutagen and antifungal compounds identified from ulam raja, e.g. cotunolide, stigmasterol, lutein and 4, 4'-bipyridine.

The objectives of this research was to determine the total phenolic content (TPC) and antioxidant activity (DPPH) of kesum, bawang putih, pegaga dan ulam raja extracts and formulated mixture extracts. The correlation of TPC with DPPH assay of pure and formulated extracts were investigated.

\section{EXPERIMENTS}

Materials. Fresh plant materials such as kesum (Polygonum minus), bawang putih (Allium sativum), pegaga (Centella asiatica) and ulam raja (Cosmos caudatus) were purchased from local market in Johor. Follin-Ciocalteu's (FC) phenol reagent was purchased from Merck, sodium carbonate anhydrous (QRëC), garlic acid (Sigma), methanol (Labscan), DPPH (2-2-Diphenyl-1picrylhydrazyl) (Sigma Aldrich) and L-ascorbic acid (Sigma Aldrich).

Determination of moisture content. About $5 \mathrm{~g}$ each single sample was dry under $105^{\circ} \mathrm{C}$. The weight of each sample was taken every one hour till the constant weight achieved [34].

Preparation of plant extracts and determination of yield. About one hundreds grams of fresh leaves kesum (Polygonum minus), pegaga (Centella asiatica), ulam raja (Cosmos caudatus) and peeled bawang putih (Allium sativum) were washed with clean water and drying the surface at $37^{\circ} \mathrm{C}$ for 30 minutes. For each plant was blended using a juice extractor without any addition of water. The juice was then filter using a whatman filter paper followed by centrifugation at $4800 \mathrm{rcf}$ at $4^{\circ} \mathrm{C}$ for 15 minutes. The filtrate were collated and used for moisture content, measuring percentage of the yield extracted. After that, the extracts were collected and store in tight glass covered with aluminum foil and kept under $-20^{\circ} \mathrm{C}$. The yield of extraction calculated as follow:

$$
\% \text { yield }=\frac{\mathrm{W}_{\mathrm{SE}}}{\mathrm{W}_{\mathrm{IE}}} \times 100 \%
$$

where $\mathrm{W}_{\mathrm{SE}}$ is weight of sample extract and $\mathrm{W}_{\mathrm{IE}}$ is weight of initial sample. Pure extracts (kesum: pegaga: ulam raja: bawang putih) were formulated with different ratios

(1:0:0:0, 0:1:0:0, 0:0:1:0, 0:0:0:1, 1:1:0:0, 1:0:1:0, 1:0:0:1, $0: 1: 1: 0,0: 1: 0: 1,0: 0: 1: 1,1: 1: 1: 0,1: 1: 0: 1,1: 0: 1: 1,0: 1: 1: 1$, $1: 1: 1: 1)$ were prepared before analyzed for total phenolic contents (TPC) and antioxidant radical scavenging (DPPH) activity.

Determination of total phenolic content (TPC). Total phenolic content for pure and formulated extracts were determined using Folin-ciocalteu following the method of Singleton (1999) [35] and Jamal et al., (2010)

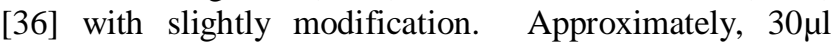
$(1 \mathrm{mg} / \mathrm{ml})$ of samples were inserted into different test tube and diluted by $2370 \mu \mathrm{l}$ of deionized distilled water and followed by $150 \mu \mathrm{l}$ of Folin-Ciocalteu reagent. Then, samples mixed well thoroughly by using vortex for $15 \mathrm{~s}$ in the dark. After one minute incubation, $450 \mu \mathrm{l}$ of $20 \%(\mathrm{w} / \mathrm{v})$ of sodium carbonate was added and allowed to react for 30 minutes at $40^{\circ} \mathrm{C}$ in the dark. The absorbance was taken at $750 \mathrm{~nm}$. All measurements were performed in three duplicate. The total phenolic acids concentration was calculated from the calibration curve, using gallic acid as the standard and the results were expressed as $\mathrm{mg} \mathrm{L}^{-1}$ of gallic acid equivalents $\left(\mathrm{GAE} \mathrm{mg} \mathrm{L}^{-1}\right)$.

Determination of free radical scavenging activity by DPPH assay. 2-2-diphenyl-1-1picrylhydrazyl (DPPH) assay was carried out to measure the antioxidant activity of pure, formulated extracts and L-ascorbic acid in terms of hydrogen donating or free radical scavenging ability [37]. The method established was based on the method described by Mavundza et al., (2010) [38] with minor modification. Sample stock solution $(1 \mathrm{mg} / \mathrm{mL})$ were freshly prepared and diluted to 2-fold dilution of methanol. An aliquot of each dilution $(100 \mu \mathrm{L})$ was added with $100 \mu \mathrm{L}$ of $0.04 \% \mathrm{DPPH}$ (Sigma Aldrich, 90\%) to each well to give final volume of $200 \mu \mathrm{L}$ equally in each well in a 96-well plate. The plate was gently shaken and incubated in dark for 30 minutes at room temperature. The absorbance (A) was measured at $517 \mathrm{~nm}$ using a microplate reader (Biotek Epoch, USA) against methanolic solution as blank. The experiment were done in triplicates. The percentage of DPPH inhibition was calculated using following formula:

$$
\% \text { inhibition }=\frac{[\mathrm{Ac}-\mathrm{As}]}{\mathrm{Ac}} \times 100 \%
$$

where $A_{C}$ is the absorbance of the control reaction (containing all reagents except the test compound) and $A_{S}$ is the absorbance of the tested compound.

Statistical Analysis. All data obtained were analyzed using SPSS version 15.0 software and Execl (Microsoft Inc). Analysis of varience (ANOVA) and Duncan Dunnet's multiple- range test were use to analyzed significant differences between samples. Pearson's correlation was used to determine the correlation between 
DPPH free radical scavenging activity (\%) on total phenolic content. Data were reported as mean \pm standard deviation.

\section{RESULTS AND DISCUSSION}

Measurement of moisture content showed that ulam raja had the highest moisture content $(89.6 \%)$, followed by pagaga, kesum and bawang putih was $89.4 \%$, $82.6 \%$ and $69 \%$ respectively. The yield of extraction showed that ulam raja had the highest yield which is $24 \%$ followed by pegaga $22.5 \%$ and bawah putih $12 \%$ while the kesum had the lowest yield of extraction (8.5\%). Also, Maizura et al., (2011) [12] shown that the kesum have lowest yield of extraction compared to ginger and turmeric.

Total phenolic content of pure and formulated extracts (kesum: pegaga: ulam raja: bawang putih) with several combination were tested using the Folin-Ciocalteu method. Table 1 shown the distribution of total phenolic content of pure and formulated extracts. For the pure extracts, the highest total phenolic content is kesum, followed by bawang putih, ulam raja and pegaga was at $1388.19 \pm 111 \mathrm{mg} \mathrm{GAE} / 100 \mathrm{~g}$ extract, $1177.87 \pm 138.82 \mathrm{mg}$ GAE/100g extract, $323.59 \pm 7.19 \mathrm{mg}$ GAE $/ 100 \mathrm{~g}$ extract and $150.01 \pm 37.93 \mathrm{mgGAE} / 100 \mathrm{~g}$ extract, respectively. Based on the highest phenolics content in kesum extract obtained, the kesum extract was subjected as control for the statistical analysis one-way ANOVA of Duncan and Dunnet multiple-range test. Besides that, the formulated extracts shown the highest total phenolic content is formulated kesum and bawang putih (1:0:0:1) was at $1703.59 \pm 152.2 \mathrm{mg} \mathrm{GAE} / 100 \mathrm{~g}$ extract compare to others formulation extracts. However, this formulation does not significantly increased $(p>0.05)$ compare to a pure kesum and bawang putih extracts. Then, followed by formulated kesum and pegaga was at 999.14 $\pm 172.317 \mathrm{mg}$ GAE/100g extract and pegaga and bawang putih which was at 993.91 $\pm 16.67 \mathrm{mg}$ GAE $/ 100 \mathrm{~g}$ extract. Other than that, the comparison between the pure extracts such as pegaga and ulam raja; and formulated combination extracts except for formulated kesum and bawang putih shown decrease significantly difference $(\mathrm{p}<0.05)$ of total phenolic content presence in extracts. According to Bolling et al., (2010) [39] the way of cultivation and climate can be counted as factors affecting the structure of phenolics and bioactive compounds. This can partly explain the wide range of variation in total phenolic content values obtained from different studies, which used the same evaluation methods. Table L. Total phenolic content of fresh plants extracts

\begin{tabular}{|c|c|}
\hline Plants estracts & $\begin{array}{l}\text { Total phenolic content (mg } \\
\text { GAE } 100 \mathrm{~g} \text { extracts) }\end{array}$ \\
\hline Kesum (Pohgonsan minac) (1.0000) & $1388.19=111^{2}$ \\
\hline Pegaga (Centerla ariatica) (0:1:0:0) & $150.01=3793^{\circ}$ \\
\hline Ulam rajs (Cosmos cmudatv) (0.0:1:0) & $323.59=7.19$ \\
\hline Brinang putih (Alinu safinum) (0:00:-1) & $1177.87=138.82^{2}$ \\
\hline Besum Peggag $(1: 1: 0: 0)$ & $999.14=172.317^{6}$ \\
\hline Kesum: Ulam raja $(1: 0: 1: 0)$ & $730.57=73.40^{6 t}$ \\
\hline Kesum: Bawang poth (100.1) & $1703.59=152.2^{2}$ \\
\hline Pegaga: Ulam raja (0:1:10) & $218.35=18.36^{\mathrm{f}}$ \\
\hline Pegage Barieng pushic $(0: 1: 0: 1)$ & $607.56=14.56^{i}$ \\
\hline Dlam rajz Barreg putih (0:0:1:1) & $710.10=120.68^{d i}$ \\
\hline Kesum: Pegaga : Ulam raja $(1: 1: 1: 0)$ & $64232=93.48^{2}$ \\
\hline Kesum: Pegaga : Buwang puth (1:1:0:1) & $993.91=16.6]^{\circ}$ \\
\hline Kesum: Clam raja: Burang path (10:1:1) & $352.63=39.976$ \\
\hline Kesum Vlam raja : Bawang prach (0:1:1:1) & $574.06=123.53^{i}$ \\
\hline Kesum: Pegaga : Ulem rija : Baxang puth (1:1:1:1) & $585.97=11.96^{2}$ \\
\hline
\end{tabular}

The antioxidant activities of pure and formulated extracts were measured by scavenging activities of the stable radical (DPPH) [40]. Table 2 presented results of the activity of free radical scavenging of plants extracts. Results showed that kesum extract had the highest DPPH radical scavenging activity $(84.45 \pm 7.33 \%)$, followed by garlic $(74.76 \pm 4.76 \%)$, ulam raja $(60.71 \pm 6.74 \%)$ and the lowest is pegaga $(40.83 \pm 26.95 \%)$. Overall results showed that kesum had highest antioxidants among the others. Previous studied by Maizura et al., (2010) [12] also found that kesum had highest antioxidant activity compare to ginger and turmeric and mixture of their extracts. This present study showed that all extracts were decrease significant different $(\mathrm{p}<0.05)$ compared to kesum extract (control). Subjected by Fuhrman et al., (2000) [41] reported that "the natural presence of antioxidant in plants and combination with other antioxidants may have an additive effect and synergistic effect". Thus, it is expected that from a simple addition will resulted greater synergistic effects in combination compared to individual extract. Also, the synergistic effect between plant polyphenols with other antioxidant present in plant material was found by Gravesan et al., (2008) [42]. In addition, Romano et al., (2009) [43] also were proved that synergistic effect occurred in combination of two chemicals. However, in 
this study, there are no synergistic effects of antioxidant activity for the mixture of plants extracts.

Table 2. Percentage of DPPH inhibition of plants extracts

\begin{tabular}{|c|c|}
\hline Plant extracts & DPPH inhibition $(\%)$ \\
\hline Kesum (Polvgomun minus) (1:0:0:0) & $84.45=733^{x}$ \\
\hline Pegaga (Cratella ariatica) (0:1:00) & $40.83=26.95^{\mathrm{i}}$ \\
\hline Vlam raja (Cosmos convahtis) (00:1:0) & $60.71=6.74^{\mathrm{jt} 6}$ \\
\hline Berang puth (Alliam sativum) (0000:1) & $74.76 \pm 4.76^{\mathrm{me}}$ \\
\hline Kesum Pegaga $(1: 10: 0)$ & $60.99=0.13^{\mathrm{ked}}$ \\
\hline Resum Ulam raja $(1: 0: 10)$ & $-49.51=22.67^{\circ}$ \\
\hline Kesum Barang path (10:0:1) & $77.72 \pm 5.59 \mathrm{k}$ \\
\hline Pegaga: Clem raja (0:1:1:0) & $53.78=7.07=$ \\
\hline Pegaga: Bartang puth (0:10:1) & $5498=11.48^{\mathrm{in} x}$ \\
\hline Wham rajz Barang potih (0:0:1:1) & $59.18=2.72^{\mathrm{ks}}$ \\
\hline Kesum Pegags : Clam raje (1:1:10) & $58.17=10.05 \mathrm{sh}$ \\
\hline Kesum Pegaga : Barang puth (1:1:0:1) & $6294=9.39 \mathrm{ghd}$ \\
\hline Resum Dam rajy Bawreg potih (10:1:1) & $60.72=0.90^{\mathrm{ked}}$ \\
\hline Kesum-Clam raja : Bawag poth (0:1:1:1) & $55.98=18.79 \mathrm{gtad}$ \\
\hline Kesum Pegaga : Clam raja : Berrang puth (1:1:1:t) & $52.98=8.93=$ \\
\hline
\end{tabular}

Values are mean $(\mathrm{n}=3)=$ standard deriation. Value with the different letter superscript are significantly differest $(\mathrm{p}<0.05)$ and same superscript letter ae not significant different (p>0.05) within each column eraluated in one-way ANOVA (Duacan and Duenet's multiple-range test).

As proposed from many studies, stated that plants, herbs and spices extracts that contain a high amount of phenolic also exhibit high antioxidant activity $(12,41)$. Pearson's correlation between total phenolic content and antioxidant activity (DPPH) indicated weak relationship where the $\mathrm{r}=0.293$. According to Shaida et al., (2011) [44], the low correlations confirm that phenolic compounds are not the only contributor to the antioxidant activities but the type and quantity of phenolic compounds and the presence of non-phenolic antioxidants may also contribute to the antioxidant activity of the extracts. Meanwhile, coefficient of determination $\left(\mathrm{r}^{2}\right)$ was measured on how well regression line represent the data which shows the non-association between total phenolic content and DPPH assay $\left(\mathrm{r}^{2}=0.115\right)$. Based on studies of Huang et al., (2005) [45], DPPH reaction presents the disadvantages which can underestimate the antioxidant capacity such as it may react slowly or be inert to many antioxidants. Reaction kinetic with antioxidants appears not linear to DPPH concentrations, and reaction of DPPH with some phenolic structures could not go to completion, reaching an equilibrium state, as found for eugenol.

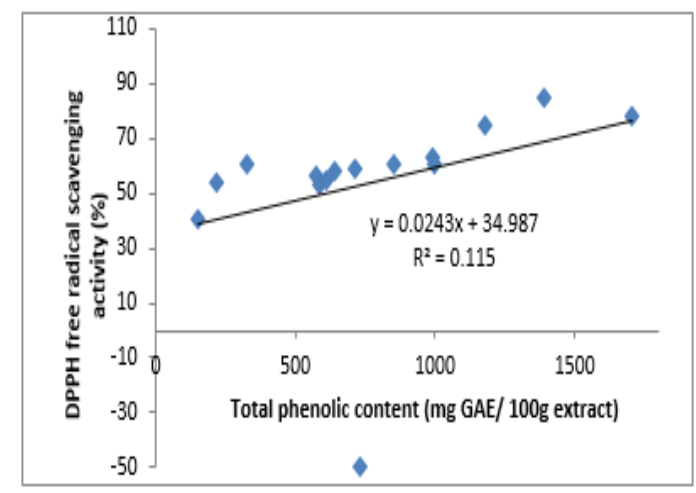

Figure 1 . The correlation between total phenolic content and antioxidant activity (DPPH fre radical-scavenging activity) of plants extracts

\section{CONCLUSION}

The results obtained demonstrated that kesum extract had highest of total phenolic content and antioxidant activity, compare to pegaga, ulam raja, bawang putih and formulated extracts. Moreover, it is found that the formulated extracts does not show any synergism effect.

\section{ACKNOWLEDGEMENTS}

The authors thank the Department of Biosciences, Faculty of Bioscience and Medical Engineering, Universiti Teknologi Malaysia, Johor and Department of Molecular Medicine, Faculty of Medicine, University of Malaya, Kuala Lumpur, Malaysia as well as to Ministry of Higher Education (MOHE) and University Grant (GUP) vot 04H06 for funding the project.

\section{REFERENCES}

[1] Sumbul, S., Ahmad, M. A., Mohd, A. and Mohd, A. J Pharm and BioAllied Sci. 3(3) (2011): 361-367

[2] Izunya, A. M., Nwaopara, A. O. and Aigibiremolen, A. Res J Appl Sci Eng Technol. 2(5) (2010): 460-465

[3] Thongchai, S., Ekalaksananan, T., Pientong, C., Aromdee, C., Seubsasana, S., Sukpoi, C. and Kongyingyoes, B. J Sci Tech MSU. 27(4) (2008): 318-326

[4] Hasima, N., Aun, L. I. L., Azmi, M. N., Aziz, A. N., Thirthagiri, E., Ibrahim, H., Awang, K. Phytomedicine. 17 (2010): 935-939

[5] Yoon, C-H., Chung, S-J., Lee, S-W., Park, Y. B., Lee, S-K. and Park, M-C. Joint Bone Spine. 80 (2013): 274-279

[6] Egua, M. O., Etuk, E. U., Bello, S. O. and Hassan, S. W. J Pharmacognosy and Phytother. 6(1) (2014): 4-9

[7] Wasman, S. Q., Mahmood, A. A., Zahra, A. A., Salmah, I., and Hamdan, S. J Med Plants Res. 4(24) (2010): 2658-2665

[8] Kishk, Y. F. M. and El Sheshetawy, H. E. World J Dairy \& Food Sci. 5(2) (2010): 188-196

[9] Kannan, R. R. R., Arumugam, R. and Anantharaman, P. Asian Pacific J Tropical Med. (2010) 898-901

[10] Sun and Ho. Food Chem. 90 (2005): 531-537

[11] Suhaj. J Food Compos Anal.19 (2006): 531-537

[12] Maizura, M., Aminah, A. and Wan Aida, W. M. Int Food Res J. 18 (2011): 529-234

[13] Krishnaiah, D., Rosalam, S. and Rajesh, N. Food and Bioproducts Processing. 89 (2011): 217-233 
[14] Ippoushi, K. A., Takeuchi, H., Xito, H., Horie, H. and Azuma, K. Food Chem. 10 (2007): 237-242

[15] Huda-Faujan, N., Noriham, A., Norrakiah, A. S. and Babji, A. S. Afr J Biotechnol. 8(3) (2009): 484-158

[16] Park J.-H., Park, Y. K. and Park, E. Plant Foods Hum Nutr. 64 (2009): 244-249

[17] Gupta, Y. K., Veerendra Kumar, M. H. and Srivastava, A. K. Pharmacol Biochem Behav. 74(3) (2003): 579-85

[18] Shui, G., Leong, L. P. and Shih, P. W. J Chromatogr B Anal. Tech. Biomed Life Sci. 827(1) (2005) : 127-38

[19] Mediani, A., Abas, F., Khatib, A. and Tan, C. P. Molecules. 18 (2013): 10452-10464

[20] Nanasombat, S. and Techchuen, N. J Med Plants Res. 3(5) (2009): 443-449

[21] Wasman, S. Q., Mahmood, A. A., Chua, L. S., Hasnah, M. S., and Hamdan, S. Int J Mol Sci. 13 (2012): 1481-1496

[22] Shukor, M. F. A., Ismail, I., Zainal, Z. and Noor, N. M. Acta Physiologiae Plantarum. (2013): 1-15.

[23] Lanzotti, V. Phytochem Rev. 11 (2012a): 179-196

[24] Ou, W. C., Chen, H. F., Zhong, Y., Liu, B. R., Liu, S. M. and Chen, K. J. Am J Med Sci. (2012): PMID 2222-2335

[25] Lanzotti, V., Barile, E., Bonanomi, G., Antignani, V. and Scala, F. Phytochemistry. 78 (2012b): 126-134

[26] Jabrane, A., Jannet, H. B., Miyamoto T, Mirjolet, J. F., Duchamp, O., Harzallah-Skhiri, F., Lacaille-Dubois, M. A. Food Chem 125 (2011): 447-455

[27] Corea, G., Fattorusso, E., Lanzotti, V., Capasso, R. and Izzo, A. A. J Agric Food Chem. 53(2005):935-940

[28] Lai, W., Wu, Z., Lin, H., Li, T., Sun, L., Chai, Y. and Chen, W. J Nat Prod. 73 (2010):1053-1057

[29] Mskhiladze, L., Legault, J., Lavoie, S., Mshvildadze, V., Kuchukhidze, J., Elias, R. and Pichette, A. Molecules. 13 (2008): 2925-2934
[30] Adao, C. R., Pereira da Silva, B., Tinoco, L. W. and Parente, J. P. Chem Biodiv. 9 (2012):58-67

[31] Abdulla, M. A., Al-Bayaty, F. H., Younis, L. T. and Abu Hassan, M. I. J Med Plants Res. 4(13) (2010): 1253-1259

[32] Abas, F., Shaari, K., Lajis, Israf, D. A. and Yusof, U. K. Nat Prod Sci. 9 (2003): 245-248

[33] Ragasa, C. Y., Nacphil, Z. D., Penalosa, B. A., Coll, J. C. and Rideout, J. A. Philipp J Sci. 126 (1999): 199-206

[34] AOAC. Association of official analytical chemist. (1990)

[35] Singleton, V. L., Orthofer, R. and Lamuela-Raventos, R. M. Methods in Enzymology. 29 (1999): 152-178

[36] Jamal, P., Barkat, A. A. and Amid, A. J Appl Sci. 10(21) (2010): 2658-2662

[37] Robards, K., Prenzler, P. D., Tucker, G., Swatsitang, P. and Glover W. Food Chem. 66 (1999): 401-436

[38] Mavundza, E., J., Tshikalange, T. E., Lall, N., Hussein, A. A., Mudau, F. N. and Meyer, J. J. M. J Med Plants Res. 4(23) (2010): 2584-2587

[39] Bolling, B. W., Dolnikowski, G., Blumberg, J. B. and Chen, C. Y. Food Chem. 122(3) (2010): 819-825

[40] Rajesh, M. P. and Natvar, J. P. J Adv Phar Education \& Res. 1 (2011): 52-68

[41] Fuhrman, B., Volcova, N., Rosenblat, M. and Aviram, M Antioxidants and Redox Signalling. 2 (2000): 491-505

[42] Gravesan, H. B., Becker, E. M., Skibsted, L. H. and Andersen, M. L. Food Res and Techn. 226(4) (2008): 737-743

[43] Romano, c., Abadi, K., Repetto, V., Vojnov, A. A., and Moreno, S. Food Chem. 115 (2009): 456-461

[44] Sulaiman, S. F., Md Yusoff, N. A., Eldeen, I. M., Seow, E. M., Abu Bakar Sajak, A., Supriatno and Ooi, K. L. J Food Composition and Analysis. 24(1) (2011): 1-10

[45] Huang, D., Ou, B. and Prior, R. L. J Agric Food Chem. 53(6) (2005): 1841-1856 